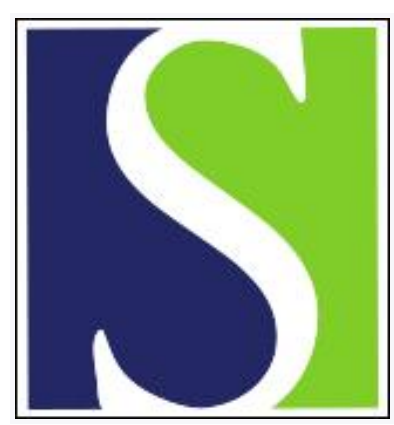

Scand J Work Environ Health 1985;11(6):427-432

https://doi.org/10.5271/sjweh.2204

Issue date: Dec 1985

\title{
Health and stress of seafarers.
}

by Elo $\mathrm{AL}$

This article in PubMed: www.ncbi.nlm.nih.gov/pubmed/4095520

\section{(c) (1)}




\title{
Health and stress of seafarers
}

\author{
by Anna-Liisa Elo, $\mathrm{PhL}^{1}$
}

\begin{abstract}
ELO A-L. Health and stress of seafarers. Scand J Work Environ Health 11 (1985) 427-432. The perceived health and stress of seafarers was studied in relation to work stressors and personality characteristics (self concept). The data were collected with a questionnaire. The study group consisted of 591 seafarers representing different occupations of the Finnish merchant fleet. Forty percent of the respondents sailed in ocean traffic, $31 \%$ on the Baltic Sea, and $29 \%$ in European traffic outside the Baltic Sea. The respondents' age averaged 35 (SD 11) years; $23 \%$ were women and $77 \%$ men. The amount of perceived stress varied between different occupational groups, the engine crew reporting the most stress. On the average, health status was reported as rather good. Personality characteristics were important explanators of perceived stress and health status. The most important were pessimism-optimism and ego strength. Of the work-related factors, the most important explanatory factors were disturbing noise, climatic conditions on board, occupational group, and received appreciation at work. The quality of interpersonal relations at work did not predict stress or health status. In this study $15-33 \%$ of the variance of perceived health status and stress could be explained.
\end{abstract}

Key terms: depression, self concept, social relations, work characteristics.

In the profession of seafaring the physical and mental load has been considered high. Both the work conditions and the content of the work contain many potential stress factors. The maneuvering of the ship has many mentally stressing phases for both the deck and engine room officers and crews. The work of the crew as a whole has proved to be primarily physically heavy, and that of the officers mentally loading. Although automation has shifted the work load more towards mental stress, the physical load of the crew can be great at times, and accident risk is involved $(6,21)$.

The most serious problems of seamen's work conditions are noise and vibration. In addition, rough seas may cause both functional and health disturbances (8). The climatic conditions on board are often poor in both hot and cold climates, and extreme changes in humidity and temperature are possible.

The social organization of a ship is traditionally hierarchical, and seafarers are separated from society and families for long periods of time. On board, living is restricted in terms of both leisure-time activities and social contacts. If social conflicts break out, they are impossible to escape. Nolan (16) has given the following examples of the restrictions on seamen: inability to obtain things and services and the lack of sexual relationships, freedom, independence and private life, security, and stimulance. Many of these social and psychological problems have been confirmed in empirical studies $(7,8,22)$.

\footnotetext{
1 Department of Psychology, Institute of Occupational Health, Helsinki, Finland.
}

Reprint requests to: Ms A-L Elo, Institute of Occupational Health, Laajaniityntie 1, SF-01620 Vantaa, Finland.
Information concerning the mental health of seafarers is rather inconsistent. According to some sources their mental health problems are increasing. The number and type of disturbances vary, but it seems that, on the average, a seaman is more subject to mental health disturbances than the general population $(18,19)$. In addition mental health problems may have more serious consequences on board a ship than elsewhere. In studies on the neuroses and functional health disorders of seafarers $(3,14,17)$, a connection has been found between work conditions, work time, and neurotic types of mental disorders.

It is supposed that both individual characteristics and work conditions influence a person's perception of stress and health. The properties of work and living conditions expose the individual to potential health risks and stress factors. They may be biological, psychological, social, or sociocultural. The individual's perception of these factors is especially important, not only because of the modifying effect of consciousness, but also because these perceptions guide behavior, eg, the health behavior of the individual $(12,15)$.

In the present study the perceived health status and stress of seafarers were examined in relation to individual and stress factors. The adopted theoretical frame of reference for stress was based on previous studies of stress in worklife $(1,9,10,11,13)$.

This study was conducted to clarify the relations of perceived stress and health status to work-related stress factors in the seafaring profession. Personality features were investigated as possible counterparts of stress factors in the explanation of stress and health. The depressive type of reaction was also analyzed in relation to work stressors and personality in parallel with the more anxiety-emphasized general stress reaction. 


\section{Subjects and methods}

\section{Subjects}

The study group consisted of 591 seafarers who responded to a questionnaire sent to a sample $(\mathrm{N}=985)$ of persons randomly chosen from the crew list of every vessel $(N=168)$ of the Finnish merchant fleet in foreign traffic at the time of study. The sample was chosen in proportion to the size of the ship crews and their occupational structures.

The subjects were sent a questionnaire, while on board ship, twice in both of the official languages of Finland (Finnish and Swedish). The trade unions, ship companies, and the seafaring authorities cooperated in every phase of the study. The response rate and age and sex distributions of the subjects in the different occupational groups are presented in table 1 .

As the response rate was relatively low, the respondents and nonrespondents were compared with respect to some background variables with the aid of trade union files. There were no differences in the age, sex, type of ship, or sea area distributions between the respondents and nonrespondents. There was however a slight overrepresentation of officers among the respondents. The relatively high proportion of women was due to the large catering staffs of the passenger ships (ferries) on the Baltic Sea.

Of the respondents $45 \%$ worked on cargo ships, $20 \%$ on tankers, $19 \%$ on passenger ships, and the rest $(16 \%)$ on other ships, which are mostly special cargo vessels. There are no ice breakers in the merchant fleet.

Twenty-eight percent of the respondents worked on the Baltic Sea, $29 \%$ in European traffic outside the Baltic Sea, and $42 \%$ in ocean traffic. The median age of the ships was 8.3 years.

The typical respondent had worked in seafaring for about 10 years, $6 \%$ had been in seafaring less than 1 year, and $19 \%$ more than 20 years. Fifty-seven percent of the respondents had received some special education for their occupation. In Finland today nearly all of the persons entering the seafaring profession has received special education, and about half of the present seafaring labor force has been professionally educated. The relatively long experience of the respondents in seafaring and the proportion of those having received special professional education reflect the slight overrepresentation of officers among the respondents.

\section{Methods}

The data were collected with a questionnaire which consisted of 194 items. The main categories of variables were: (i) background information concerning the individual and ship, (ii) work characteristics, (iii) social relations, (iv) subjective stress reactions and perceived health, and (v) personality (self concept).

Work characteristics can be divided in several ways into subcategories. In this study the characteristics measured were chosen on the basis of previous studies on seafaring and on stress in various branches of worklife. The data reduction was made on the basis of the distributions, correlations, and factor analyses within the variables of self-concept and stress reactions. The complete list of variables used as predictors is given in table 2. These cover the main features of the work environment, work organization, work content, and work background. A measure of the seafarers' work environment was constructed on the basis of the following qualitative variable: "Which one of the following factors disturbs you most when on board ship?" The variable was dichotomized for the regression analyses: rough seas versus other disturbing factors. Also one question concerning home-related problems was added to the potential stress factors. The main features of social environment in this study were the social climate of one's own work area and appreciation received from the others on board.

Personality characteristics were measured by a selfinventory of 22 items based on the method of semantic differential presented, eg, by Kalimo (10). The inventory reflects the concept of self. Two sum scales were constructed out of these variables, ie, ego strength, which reflects self-control (four items, Cronbach's $\alpha=0.70$ ), and introversion-extroversion (three items, Cronbach's $\alpha=0.69$ ). In addition to these two scales a single item was chosen to measure pessimismoptimism, which indicates a person's manner of anticipating the future.

Table 1. Response rate, age, and sex of the different occupational groups.

\begin{tabular}{|c|c|c|c|c|c|}
\hline \multirow{2}{*}{ Occupational group } & \multirow{2}{*}{$\begin{array}{l}\text { Study group } \\
\text { (N) }\end{array}$} & \multirow{2}{*}{$\begin{array}{c}\text { Response rate } \\
(\%)\end{array}$} & \multirow{2}{*}{$\begin{array}{c}\text { Mean age } \\
\text { (years) }\end{array}$} & \multicolumn{2}{|c|}{ Sex } \\
\hline & & & & Female (\%) & Male $(\%)$ \\
\hline $\begin{array}{l}\text { Deck officers } \\
\text { Deck crew } \\
\text { Engine officers } \\
\text { Engine crew } \\
\text { Chief stewards } \\
\text { Catering staff } \\
\text { Radio operators }\end{array}$ & $\begin{array}{r}75 \\
109 \\
61 \\
89 \\
53 \\
136 \\
68\end{array}$ & $\begin{array}{l}69 \\
48 \\
54 \\
48 \\
70 \\
59 \\
72\end{array}$ & $\begin{array}{l}38 \\
31 \\
41 \\
33 \\
36 \\
35 \\
37\end{array}$ & $\begin{array}{r}3 \\
3 \\
0 \\
1 \\
13 \\
81 \\
12\end{array}$ & $\begin{array}{r}97 \\
97 \\
100 \\
99 \\
87 \\
19 \\
88\end{array}$ \\
\hline Total & 591 & 60 & 35 & 23 & 77 \\
\hline
\end{tabular}


Health status and stress were originally measured with 26 variables, which were, for the most part, different psychic and somatic symptom questions $(2,10)$. Of these variables, two single variables and one sum scale were chosen on the basis of factor analyses to reflect health and stress. The single questions were: "By stress we mean a situation in which you feel tense, restless, irritated, anxious or you have difficulties sleeping because things are bothering you. Do you currently feel this kind of stress?" and "How do you consider your health when compared to that of other people of the same age?" These questions have been used in several Finnish epidemiologic studies, eg, that of Kalimo (10). In addition a sum scale of five items was constructed to measure depression. The internal consistency of the scale was 0.72 (Cronbach's $\alpha$ ).

\section{Data analysis}

Descriptive analyses were carried out by calculating the percentage distributions by occupation and age and the means and standard deviations of the variables. Chi squares, $t$-tests, and analyses of variance (F-test) were used to test the differences between the occupational and age groups. Regression analyses were used to test the interdependencies between the predictors and the dependent variables. The forward type stepwise linear technique was applied. The analysis started with that predictor which had the highest correlation with the criterion variable. New variables were added to the model until their values for additional explained variance remained under the chosen critical value, which was $\mathrm{p}<0.05$ (F-test).

\section{Results}

\section{Work characteristics}

This description of the characteristics and stress factors of the seafaring profession is based on percentage distributions within the occupational and age groups. Only the statistically significant differences are reported.

Seafarers experienced noise, draft, and heat as disturbing factors on board ship. A typical problem of seafaring, rough seas, was assessed as the most disturbing by $50 \%$ of the respondents. There were no differences between the occupational groups with respect to rough seas being the most disturbing environmental factor.

The engine officers and engine crew experienced more disturbing factors in their work environment than the other occupational groups, namely, noise, draft, and heat. The deck crew perceived coldness, humidity, and unclean air as the most disturbing factors. The ratings of the deck officers and chief stewards represented the average for the different disturbing work condition variables, and those of the catering staff and radio operators were the lowest. However, the radio operators frequently perceived noise and vibration as work disturbances.

About half of the seafarers perceived the content of their work as challenging and considered it to offer possibilities for them to use their skills and knowledge. This was especially the opinion of the officers, whereas the catering staff and deck crew believed that the content of their work was very limited.

Work pace was perceived more often as fast (44\%) than slow $(13 \%)$. The deck officers, chief stewards, and catering staff more often reported the work pace to be fast, and radio operators slow. The distribution of work within one's own work area was considered fair by most of the respondents $(75 \%)$, except by the catering staff.

The distribution of work and leisure time on board was considered good by $70 \%$ of the respondents. Thirty percent were of the opinion that the organization of the workhours disturbed their sleep, especially the deck and engine officers and the deck crew.

The profession of seafaring was considered, in general, monotonous, ie, almost half of the respondents, especially the radio operators, perceived their work as such.

\section{Social relations and personality}

The relations between shipmates and between the officers and their crews were perceived as good by 69 and $82 \%$ of the respondents, respectively. Less than $10 \%$ expressed a negative opinion on these questions. Appreciation by others was perceived rather as high $(38 \%)$ than as low $(17 \%)$. In general the officers experienced more appreciation.

There were no statistically significant differences in self-concept between the occupational groups.

\section{Perceived stress and health}

The seafarers perceived their health as rather good. The differences between the age and occupational groups were not significant. However, the seafarers experienced a relatively great amount of stress, and it varied between the occupational groups $(\mathrm{p}<0.05)$ (table 2).

The highest levels of stress and depression and the lowest level of health status were reported by the engine crew. The relatively healthiest and least stressed group was the catering staff (table 2).

\section{Individual and work-related factors as predictors of} perceived health, stress and depression

Altogether 22 variables were chosen on the basis of intercorrelations as potential predictors of perceived health status, stress, and depression (table 3 ). The same predictors were used in all the regression analyses. The qualitative variables of occupation, sea area (Baltic, 
Table 2. Perceived health status, stress, and depression according to occupational group. ${ }^{\text {a }}$

\begin{tabular}{|c|c|c|c|c|c|c|}
\hline \multirow{2}{*}{ Occupational group } & \multicolumn{2}{|c|}{$\begin{array}{c}\text { Perceived } \\
\text { health status }\end{array}$} & \multicolumn{2}{|c|}{ Stress } & \multicolumn{2}{|c|}{ Depression } \\
\hline & Mean & SD & Mean & SD & Mean & SD \\
\hline $\begin{array}{l}\text { Deck officers } \\
\text { Deck crew } \\
\text { Engine officers } \\
\text { Engine crew } \\
\text { Chief stewards } \\
\text { Catering staff } \\
\text { Radio operators }\end{array}$ & $\begin{array}{l}3.6 \\
3.7 \\
3.8 \\
3.5 \\
3.6 \\
3.9 \\
3.6\end{array}$ & $\begin{array}{l}0.8 \\
0.9 \\
0.7 \\
0.8 \\
0.8 \\
0.9 \\
0.9\end{array}$ & $\begin{array}{l}2.4 \\
2.2 \\
2.5 \\
2.5 \\
2.3 \\
1.9 \\
2.3\end{array}$ & $\begin{array}{l}1.1 \\
1.1 \\
1.2 \\
1.2 \\
1.1 \\
0.9 \\
1.1\end{array}$ & $\begin{array}{l}6.9 \\
6.6 \\
6.9 \\
7.6 \\
6.7 \\
6.8 \\
6.9\end{array}$ & $\begin{array}{l}1.7 \\
1.7 \\
1.8 \\
2.1 \\
2.1 \\
2.0 \\
2.1\end{array}$ \\
\hline Total & 3.7 & 0.9 & 2.3 & 1.1 & 6.9 & 2.0 \\
\hline $\mathbf{F}$ & \multicolumn{2}{|c|}{$2.69 \mathrm{NS}$} & \multicolumn{2}{|l|}{$4.01^{*}$} & \multicolumn{2}{|c|}{2.66 NS } \\
\hline
\end{tabular}

a The scales used for the variables are health status $1-5$, stress $1-5$, and depression $3-15$.

* $p<0.05$, NS = not significant.

Table 3. Means and standard deviations of the predictors and the correlations of the quantitative predictors to perceived health status, stress, and depression $(\mathrm{N}=591)$.

\begin{tabular}{|c|c|c|c|c|c|}
\hline \multirow[b]{2}{*}{ Predictor } & \multirow[b]{2}{*}{ Mean } & \multirow[b]{2}{*}{ SD } & \multicolumn{3}{|c|}{ Dependent variable ${ }^{a}$} \\
\hline & & & $\begin{array}{l}\text { Health } \\
\text { status }\end{array}$ & Stress & Depression \\
\hline \multicolumn{6}{|l|}{ Individual factors } \\
\hline $\begin{array}{l}\text { Age } \\
\text { Ego strength } \\
\text { Extroversion-introversion } \\
\text { Pessimism-optimism } \\
\text { Worry concerning loved ones on shore }\end{array}$ & $\begin{array}{r}35.4 \\
14.0 \\
8.5 \\
3.3 \\
3.1\end{array}$ & $\begin{array}{r}11.2 \\
3.6 \\
1.8 \\
1.3 \\
1.1\end{array}$ & $\begin{array}{r}0.05 \\
0.17 \\
-0.17 \\
0.25 \\
-0.09\end{array}$ & $\begin{array}{r}0.00 \\
-0.24 \\
0.18 \\
-0.37 \\
0.28\end{array}$ & $\begin{array}{r}-0.06 \\
0.08 \\
0.32 \\
-0.37 \\
0.24\end{array}$ \\
\hline \multicolumn{6}{|l|}{ Work-related factors } \\
\hline $\begin{array}{l}\text { Occupation } \\
\text { Sea area } \\
\text { Type of ship } \\
\text { Rough seas versus other disturbing factors } \\
\text { Rough seas causing problems } \\
\text { Noise disturbing } \\
\text { Climatic conditions disturbing } \\
\text { Sequence of work-leisure on board } \\
\text { Work pace } \\
\text { Variability-monotony } \\
\text { Possibilities to use skills and knowledge (lack of) } \\
\text { Control over work (lack of) } \\
\text { Distribution of work (unfairness) } \\
\text { Insecurity in one's employment } \\
\text { Time spent on board at the time of the study } \\
\text { Appreciation (lack of) } \\
\text { Social climate between shipmates }\end{array}$ & $\begin{array}{l}: \\
\cdot \\
i .4 \\
7.1 \\
7.8 \\
2.2 \\
3.3 \\
3.2 \\
2.6 \\
2.4 \\
2.2 \\
2.9 \\
3.5 \\
2.8 \\
2.2\end{array}$ & $\begin{array}{l}. \\
. \\
0.7 \\
2.8 \\
2.6 \\
0.9 \\
0.8 \\
1.1 \\
1.8 \\
1.2 \\
1.0 \\
1.1 \\
1.6 \\
0.9 \\
0.9\end{array}$ & $\begin{array}{l}: \\
\dot{0} \\
0.00 \\
-0.15 \\
-0.19 \\
-0.09 \\
-0.02 \\
-0.08 \\
-0.09 \\
-0.05 \\
-0.10 \\
-0.13 \\
0.04 \\
-0.22 \\
-0.09\end{array}$ & $\begin{array}{l}\cdot \\
\dot{ } \\
\dot{0} .07 \\
0.34 \\
0.23 \\
0.14 \\
0.15 \\
0.17 \\
0.06 \\
0.04 \\
0.20 \\
0.16 \\
0.03 \\
0.09 \\
0.17\end{array}$ & $\begin{array}{l}\cdot \\
: \\
. \\
0.06 \\
0.24 \\
0.23 \\
0.13 \\
0.03 \\
0.14 \\
0.15 \\
0.06 \\
0.18 \\
0.15 \\
0.02 \\
0.22 \\
0.19\end{array}$ \\
\hline
\end{tabular}

a $r>0.08=p<0.05 ; r>0.11=p<0.01 ; r>0.13=p<0.001$.

European, or ocean), type of ship, and "rough seas versus other disturbing work conditions" were included in the regression analyses.

\section{Perceived health status}

Both personality features and work-related factors were predictors of perceived health status. All three personality variables, ie, ego strength, introversionextroversion and pessimism-optimism, entered into the regression model. Of the work-related factors the most important were "received appreciation on board" and "lack of disturbing noise and climatic conditions." In this analysis $15.4 \%$ of the variance of perceived health status could be explained (table 4).

\section{Experienced stress}

The stress experienced by the seafarers was best predicted by the work-related factors of disturbing noise and occupation. The most important personality factors predicting stress were pessimism-optimism and ego strength. In addition the individual stress factor "worry concerning loved ones on shore" entered the regression model. Unfairness of the distribution of work, fast work pace, variability-monotony, and sailing on the Baltic sea or in ocean traffic were also work-related, statistically significant predictors of stress.

Eleven predictors exceeded the statistical significance level of $\mathrm{p}=0.05$ and explained $33 \%$ of the total variation of experienced stress. 


\section{Depression}

The experienced depression of the seafarers was strongly connected to the personality factors of extroversionintroversion and optimism-pessimism. The workrelated factors of disturbing noise and climatic conditions, as well as those of received appreciation and occupation, entered into the regression model. Depression was the only health indicator connected with age, and the connection was reversed - the younger were more depressed. The type of occupational group was not quite consistent as a predictor of depression. However, belonging to the engine crew predicted depression consistently and belonging to the deck crew was a contraindicator of it. In addition those who were worried about loved ones on shore were more depressed than others. Altogether $28.9 \%$ of the total variation in depression could be explained in this analysis.

\section{Discussion}

The seafarers perceived their health to be rather good. The self-evaluation of health has proved to correspond rather well with clinically diagnosed health status, with the exception of cases of severe mental disorders $(5,15)$. However, the amount of stress was rather high. The perceived stress in different occupations cor- responded to that reported in previous studies of seafaring professions, except for the catering staff (4).

The relatively good health status may be due to selection. On one hand, Finnish seafaring staff receive regular and well organized health examinations, and on the other the demands of the profession do not tolerate any handicaps or lowered health status. The perceived health status did not vary with respect to occupational group or age. The independence between health and age may also be due to secondary selection; the less healthy workers, who are usually older, quit the profession.

The engine crew was the most stressed group. It differed negatively from the others also in relation to perceived health status and depression. The engine and deck officers were also relatively stressed. The radio operators and chief stewards represented the average ratings on different health and stress indicators. The catering staff perceived their health to be surprisingly better than the average, and also the deck crew was less stressed and depressed than the other workers.

Work conditions in the engine room, ie, noise and solitary work, have been previously considered one main reason for the stress and neurotic symptoms of engine room personnel. In this study also, the engine crew and officers reported more problems connected with the work environment than the other groups did.

Table 4. Regression analyses for perceived health status, stress, and depression $(N=591)$.

\begin{tabular}{|c|c|c|c|c|}
\hline \multirow{2}{*}{$\begin{array}{l}\begin{array}{l}\text { Dependent } \\
\text { variable }\end{array} \\
\text { Perceived } \\
\text { health status }\end{array}$} & \multirow{2}{*}{$\begin{array}{l}\text { Predictor } \\
\text { Pessimism-optimism } \\
\text { Appreciation (lack of) } \\
\text { Catering staff } \\
\text { Ego strength } \\
\text { Extroversion-introversion } \\
\text { Climatic conditions disturbing }\end{array}$} & \multirow{2}{*}{$\begin{array}{c}\text { Regression } \\
\text { coefficient } \\
0.08 \\
-0.17 \\
0.27 \\
0.04 \\
-0.04 \\
-0.04\end{array}$} & \multicolumn{2}{|c|}{$\begin{array}{l}\text { Standardized regression } \\
\text { t-value coefficient }\end{array}$} \\
\hline & & & $\begin{array}{r}0.11 \\
-0.17 \\
0.13 \\
0.16 \\
-0.13 \\
-0.12\end{array}$ & $\begin{array}{r}2.6^{* \star} \\
-4.4^{* * *} \\
3.5^{* * *} \\
4.0^{* * *} \\
-3.2^{* * *} \\
-3.1^{* \star *}\end{array}$ \\
\hline & Total variation explained $15.4 \%, F=1$ & & & \\
\hline \multirow[t]{2}{*}{ Stress } & $\begin{array}{l}\text { Pessimism-optimism } \\
\text { Noise disturbing } \\
\text { Ego strength } \\
\text { Catering staff } \\
\text { Worry concerning loved ones on shore } \\
\text { Distribution of work (unfair) } \\
\text { Deck crew } \\
\text { Work pace } \\
\text { Variability-monotony } \\
\text { European traffic }\end{array}$ & $\begin{array}{r}-0.21 \\
0.07 \\
-0.05 \\
-0.65 \\
0.15 \\
0.14 \\
-0.30 \\
0.13 \\
0.10 \\
-0.19\end{array}$ & $\begin{array}{r}-0.24 \\
0.17 \\
-0.17 \\
-0.25 \\
0.15 \\
0.13 \\
-0.11 \\
0.09 \\
0.09 \\
-0.08\end{array}$ & $\begin{array}{r}-6.7^{\star \star \star} \\
4.5^{\star \star \star} \\
-4.8^{\star \star \star} \\
-6.7^{\star \star *} \\
4.3^{\star \star \star} \\
3.8^{\star \star \star} \\
-3.0^{\star \star} \\
2.7^{\star \star} \\
2.6^{\star *} \\
-2.3^{\star}\end{array}$ \\
\hline & Total variation explained $33.2 \%, F=2$ & & & \\
\hline \multirow[t]{2}{*}{ Depression } & $\begin{array}{l}\text { Pessimism-optimism } \\
\text { Extroversion-introversion } \\
\text { Noise disturbing } \\
\text { Worry concerning loved ones on shore } \\
\text { Engine crew } \\
\text { Appreciation (lack of) } \\
\text { Age } \\
\text { Deck crew } \\
\text { Climatic conditions disturbing }\end{array}$ & $\begin{array}{r}-0.29 \\
0.17 \\
0.08 \\
0.26 \\
0.52 \\
0.27 \\
-0.02 \\
-0.46 \\
0.07\end{array}$ & $\begin{array}{r}-0.19 \\
0.26 \\
0.12 \\
0.15 \\
0.09 \\
0.12 \\
-0.12 \\
-0.09 \\
0.09\end{array}$ & 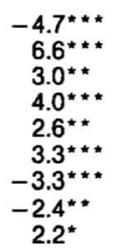 \\
\hline & Total variation explained $28.9 \%, F=2$ & & & \\
\hline
\end{tabular}

* $p<0.05,{ }^{* *} p<0.01,{ }^{* *} p<0.001$. 
The good perceived health status and low stress level of the catering staff was an unexpected result, especially because this was the "female group" of the study. Women usually report more symptoms and lower health status than men. Most of the catering staff were sailing on the Baltic Sea, where the routes are short and the work-leisure schedules are regular. These factors have been considered an advantage in relation to stress in seafaring even though the work pace may be fast on short routes. In addition the catering staff have usually received special schooling for hotel and restaurant work, and they are thus not so strongly bound to the seafaring profession as some of the other groups. Thus the selection of this occupational group may differ from that of the other groups.

Perceived health status, stress, and depression were partly explained by the same individual and workrelated factors. Pessimism-optimism, occupation, and disturbing noise had importance in the variation of all these three indicators of well-being. Contrary to expectation, the quality of the social relations did not predict any of these indicators. The result is especially surprising in a socially closed organization.

Personality factors and appreciation received at work were the best predictors of health status. It seems that in a relatively healthy group the personality features have a pronounced importance in the self-evaluation of health.

Of the studied health indicators, stress was the most strongly connected to the work-related factors. Noise, occupation, unfair distribution of work, fast work pace, and monotony were predictors of it, in addition to personality features.

One important predictor of stress and depression was worry about loved ones on shore. This result not only reflects real family problems, but also the inability to control home-related matters. It is obvious that the connections between seafarers and their home and society compose a major source of stress.

According to the results, both personality factors and work-related factors are important predictors of well-being. The pronounced role of personality in the prediction of health and stress may be partly due to the good health status but partly also to the measures of personality. The most important predictor, pessimism-optimism, was operationalized as anticipation of the future. This kind of attitude is probably reflected in the evaluation of one's self, and living and work conditions as well. The cross-sectional study design and the self-reportive methodology used set limitations, however, for the indepth analysis of cause-and-effect relationships. On the other hand the problem of work-related health status and stress is not a unidirectional cause-and-effect issue. People can and do actively cope with their stress, and personality features have an important role in this process.

\section{References}

1. Caplan RD, Cobb S, French JRP, Harrison R, Pinneau SR. Job demands and worker health: Main effects and occupational differences. US Department of Health, Education and Welfare, Washington DC 1975.

2. Derogatis LR, Lipman RS, Covi L. An outpatient psychiatric rating scale - Preliminary report. Psychopharmacol Bull 9 (1973) 13-28.

3. Dolmierski R, De Walden KJ. Environmental factors causing neurosis in seamen. Bull Inst Marit Trop Med Gdynia 23 (1972) 7-13.

4. Elo A-L. Merenkulkijoiden työ ja mielenterveys. Institute of Occupational Health, Helsinki 1979. (Katsaus 27).

5. Garrity TF, Somes GW, Marx MB. Factors influencing self assessment of health. Soc Sci Med 12 (1978) 77-81.

6. Goethe H, Zorn E, Hermann R, Schepers B-F. Die psychophysische Belastung des Personals moderner Seeschiffe als aktuelles Problem der Schiffarhrtsmedizin. Zentralbl Bakteriol I Abt Orig B Hyg Krankenhaushyg Betriebshyg Präv Med 166 (1978) 1-36.

7. Horbulewicz J. From studies on the influence of work on the personality of man in nautical environment. Biul Inst Med Morsk Gdansku 17 (1966) 379-381.

8. Ivergård $\mathrm{T}$, Ekelin $\mathrm{A}$, Lundberg $\mathrm{M}$, Norberg $\mathrm{L}$, Svedung I. Arbetsmiljö inom Sjöfarten. Sjöfartens Arbetarskyddsnämnd, Stockholm 1978.

9. Jenkins CD. Psychosocial modifiers of response to stress. J Hum Stress 5 (1979) 3-15.

10. Kalimo R. Stress in work: Conceptual analysis and study on prison personnel. Scand J Work Environ Health 6 (1980): suppl 3, 1-124.

11. LaRocco JA, House JS, French JRP. Social support, occupational stress, and health. J Health Soc Behav 21 (1980) 202-218.

12. Lazarus RS. Psychological stress and the coping process McGraw-Hill Book Company, New York, NY 1966.

13. Levi L. Stress and distress in response to psychosocial stimuli. Acta Med Scand 191 (1972): suppl 528, 1-149.

14. Matsevitch LM, Poroshenko AS. The influence of the duration of a voyage on the functional state of a seaman's body. Bull Inst Marit Trop Med Gdynia 25 (1974) 443-446.

15. Mechanic D. Effects of psychological distress on perceptions of physical health and use of medical and psychiatric facilities. J Hum Stress 4 (1978) 26-32.

16. Nolan B. A possible perspective on deprivation. In: Fricke PH, ed. Seafarer \& community. Croom HelmLtd, London 1973.

17. Stenko UM, Tkachenko VD, Hramtsova ST. The socialpsychological aspects of fishermen who are out at sea for a long time. In: Ministry of Health, Research Institute of Water Transport Hygiene of the USSR. VII international symposium of marine medicine, Odessa. Moscow 1976.

18. Sundby P. Occupation and insanity. Acta Psychiatr Scand 25 (1958): suppl 106, 276-287.

19. Tenfjord OW. Mental diseases among Norwegian seamen. Biul Inst Med Morsk Gdansku 17 (1966) 373-377.

20. Werthén H-E. De ombordanställdas arbetsförhållanden och trivsel: Del II Huvudresultat och rekommendationer. The Swedish Ship Research Foundation, Göteborg 1973. (Svensk skeppsforskning, rapport nr 87).

21. Zorn E. Die Arbeitsplätze in der heutigen Handelsschiffahrt aus arbeitsmedizinischer Sicht. Arbeitsmed Sozialmed Arbeitshyg 6 (1970) 139-142.

Received for publication: 6 May 1985 